\title{
ANALISIS KEPUTUSAN PEMBELIAN JASA PENAMBANGAN PT BERAU COAL KEPADA PT BUKIT MAKMUR MANDIRI UTAMA (BUMA)
}

\author{
Arifin Sitio', Beni Rasjid ${ }^{2}$ \\ 1Fakultas Ekonomi dan Bisnis, Universitas Mercubuana, Indonesia \\ Email : Arifin.sitio@mercubuanauniversity.ac.id \\ 2Magister Manajemen, Fakultas Ekonomi dan Bisnis, Universitas Mercubuana, Indonesia. \\ Email : Rasjid.beni@gmail.com
}

\section{ARTICLE INFO}

Keywords :

Quality of services, people, processes and physical evidence, service purchasing decisions

\section{How to cite :}

Sitio, Arifin., Rasjid, Beni (2018). Analisis Keputusan Pembelian Jasa Penambangan PT Berau Coal Kepada PT Bukit Makmur Mandiri Utama (Buma) . JMM UNRAM, 7(2), 17 - 35

DOI :

10.29303/jmm.v7i2.315

\begin{abstract}
This study aims to find out the influence of the quality of services, people, processes and physical evidence on the decision to purchase mining services by PT Berau Coal to PT BUMA. In this study, data collection was carried out through survey methods by distributing questionnaires to respondents within the company organization PT Berau Coal starting from the position of supervisor /engineer to general manager. The number of samples taken in this study was 50 people. Thetechnique sampling used in this study is Simple Random Sampling. Data analysis method uses multiple regression analysis with SPSS 23.0. The results of data processing show that the variable quality of services, people, processes and physical evidence affect the decision to purchase mining services. Parameters for testing the effect of service quality on service purchasing decisions show a $t$ value of 3.191 ( $\mathrm{sig}=$ 0.003), the influence of people on the decision to purchase services shows a t value of 2.341 (sig $=0.024)$, the effect of the process on the decision to purchase services shows a t value of 2.400 ( $\operatorname{sig}=0.021)$, and the effect of physical evidence on the decision to purchase services shows a t value of 2.797 (sig $=$ 0.008).
\end{abstract}

Penelitian ini bertujuan untuk mengetahui pengaruh kualitas layanan, orang, proses dan bukti fisik terhadap keputusan pembelian jasa penambangan oleh PT Berau Coal kepada PT BUMA. Dalam penelitian ini, pengumpulan data dilakukan melalui metode survei dengan menyebarkan kuesioner kepada responden dalam organisasi perusahaan PT Berau Coal mulai dari posisi supervisor / insinyur hingga general manager. Jumlah sampel yang diambil dalam penelitian ini adalah 50 
orang. Teknik sampling yang digunakan dalam penelitian ini adalah Simple Random Sampling. Metode analisis data menggunakan analisis regresi berganda dengan SPSS 23.0. Hasil pengolahan data menunjukkan bahwa variabel kualitas layanan, orang, proses dan bukti fisik mempengaruhi keputusan untuk membeli jasa penambangan. Parameter untuk menguji pengaruh kualitas layanan pada keputusan pembelian layanan menunjukkan pada nilai 3,191 (sig = 0,003), pengaruh orang pada keputusan untuk membeli layanan menunjukkan pada nilai 2,331 (sig =0,024), efek dari proses pada keputusan untuk membeli layanan menunjukkan pada nilai 2.400 (sig =0,021), dan pengaruh bukti fisik pada keputusan untuk membeli layanan menunjukkan pada nilai 2,797 (sig =0,008).

Copyright $\odot 2018$ JMM UNRAM. All rights reserved.

\section{PENDAHULUAN}

Kebutuhan energi dunia dari semua skenario kecenderungan terus naik dan bahan bakar fosil masih mendominasi. Pada periode tahun 2011 sampai dengan 2035, kebutuhan batubara mengalami peningkatan terbesar dibanding bahan bakar fosil lainnya dan mulai tahun 2020 mengambil alih peran minyak atau terbesar dalam bauran energi primer. sejak tahun 2000 hingga tahun 2035 pemakaian energi terus naik. BBM masih terus mendominasi dan konsumsi batubara terus meningkat (prediksi kelipatan 10 tahunan) meski ada kekuatiran isu lingkungan.

Indonesia adalah salah satu produsen batubara dunia. Cadangan batubara Indonesia sampai dengan 2013 mencapai sebesar 28,97 Miliar Ton, sedangkan sumber daya batubara mencapai 119,82 miliar Ton dengan rincian sumberdaya terukur sebesar 39,45 miliar Ton, terindikasi sebesar 29,44 miliar Ton, tereka sebesar 32,08 miliar Ton dan hipotetik sebesar 19,56 miliar T. Pemerintah melalui kementrian Energi dan Sumber Daya Mineral mengusahakan penambangan batubara ini agar bermanfaat bagi masyarakat dan rakyat Indonesia dengan melakukan kerjasama dengan pihak swasta. Pihak swasta inilah yang ditunjuk oleh pemerintah untuk melakukan usaha pertambangan batubara dengan memberikan izin konsesi pengusahaan. Dari sekian perusahaan yang di tunjuk oleh pemerintah, PT Berau Coal adalah salah satu perusahaan pemegang hak pengusahaan batubara di wilayah Kalimantan Timur, tepatnya di kabupaten Berau.

PT Berau Coal adalah salah satu pemegang hak pengusahaan batubara (PKP2B) generasi pertama yg di tanda tangani pemerintah Indonesia di tahun 1981 dengan luas konsesi sekitar 118.000 hektar. PT Berau Coal melakukan pengusahaan tahapan penambangannya tidak di lakukan sendiri. Ia menunjuk perusahaan lain sebagai kontraktor untuk melakukan tahapan pekerjaan penambangan. Beberapa kontraktor yang di tunjuk oleh PT Berau Coal adalah PT Bukit Makmur Mandiri Utama (BUMA), PT Pama Persada Nusantara (PAMA), PT Sapta Indra sejati (SIS), PT Ricobana Abadi (RBA), PT Darma Henwa (DH). PT Madhani Talatah Nusantara (MTN), PT Riung Mitra Lestari (RML), PT Mutiara Tanjung Lestari (MTL). Dari semua perusahaan di atas tersebut tidak semua mampu bertahan menjalankan bisnisnya di area Berau Coal. Dengan tantangan di awal 2010 hingga 2015 yang berat karena harga 
komoditas yang anjlok menyisakan BUMA, PAMA, SIS, RBA, dan MTL yang didalamnya telah melakukan re-struktur kerjasama usaha masing-masing.

Kondisi ini menunjukan kapasitas dari perusahaan dalam menjaga kelangsungan usaha tersebut. BUMA berhasil menjaga performa bisnisnya bersama-sama dengan PT Berau Coal di tengah kondisi yang sulit selama 5 tahun terakhir bahkan PT Berau Coal memutuskan untuk menjalin kerjasama lebih lanjut dengan membeli jasa penambangan pada tahun 2016 lalu berupa penambahan volume penambangan khususnya di area Lati hingga lebih dari 2 kali lipat di banding pekerjaan yang sedang di jalankan. Hal ini patut di cermati karena di tengah kondisi ekonomi sulit, harga batubara yang sedang lesu, kontraktor tambang yang tersedia makin banyak karena kapasitas berlebih, namun pihak PT Berau Coal memutuskan membeli jasa penambangan tersebut kepada BUMA.

Dari data yang di miliki perusahan BUMA bahwa capaian produksi yang di berikan oleh konsumen PT Berau Coal dapat terpenuhi baik itu overburden maupun batubara. Pencapaian ini tentu di dukung oleh orang-orang/karyawan yang kompeten, proses kerja yang terkendali dengan peralatan dan fasilitas pendukung yang memadai. Hal tersebut yang mendasari peneliti melakukan kajian dengan judul "Analisis Keputusan Pembelian Jasa Penambangan PT Berau Coal kepada PT Bukitmakmur Mandiri Utama (BUMA). Penelitian ini memiliki tujuan untuk menganalisis dan mengetahui mengenai pengaruh kualitas jasa, orang-orang perusahaan, proses kerja dan bukti fisik terhadap keputusan pembelian jasa penambangan oleh konsumen PT Berau Coal. Pertanyaan penelitian (kuezioner) sendiri berupa pertanyaan untuk mengetahui (1) Pengaruh kualitas jasa pada keputusan pembelian jasa oleh konsumen, (2) pengaruh orang terhadap keputusan pembelian jasa oleh konsumen, (3) pengaruh proses kerja terhadap keputusan pembelian jasa oleh konsumen, (4) pengaruh bukti fisik perusahaan terhadap keputusan pembelian jasa oleh konsumen.

Penelitian ini sendiri memiliki batasan yaitu : (1) hanya di teliti 4 variabel terikat dan 1 variabel bebas, (2) lokasi penelitian hanya di lakukan di area kerja BUMA job site Lati Mining Operation, (3) pelaksanaan penelitian hanya satu waktu bukan berkala, (4) responden terbatas dari mulai level pengawas hingga general manager. Sedangkan kegunaan dari penelitian ini adalah (1) diharapkan mempunyai kontribusi terhadap pengembangan ilmu pengetahuan khususnya untuk masalah kepuasan konsumen pada pemasaran produk jasa, (2) untuk informasi peningkatan kualitas layanan dari BUMA di harapkan bisa menjadi referensi dan membuka peluang untuk mendapat kesempatan memperluas pasar atau pelanggan baru, (3) sebagai bahan pertimbangan manajerial perusahaan untuk menentukan langkah strategis ke depan dalam menjaga kepercayaan konsumen yang pada ujungnya adalah kemenerusaan kontrak dan menjaga level volume produksi.

\section{KAJIAN TEORI , KERANGKA PEMIKIRAN DAN HIPOTESIS}

\subsection{Kajian Teori}

Kualitas Jasa $\left(\mathbf{X}_{\mathbf{1}}\right)$. Kotler dalam Tjiptono (2005:16) menyatakan bahwa jasa sebagai salah satu bentuk produk yang didefinisikan sebagai: setiap tindakan atau perbuatan yang dapat ditawarkan oleh suatu pihak kepada pihak lain yang pada dasarnya bersifat intangible (tidak berwujud) dan tidak menghasilkan kepemilikan tertentu. Menurut Lupioyadi - Hamdani Kualitas jasa adalah sejauh mana jasa memenuhi spesifikasi-spesifikasinya atau dengan kata lain suatu tingkat perbedaan antara kenyataan dan harapan pelanggan atas layanan yang mereka terima. Parasuraman (et all. 1988) menyederhanakan dari sepuluh dimensi kualitas 


\section{NATIONALLY ACCREDITED JOURNAL - DECREE NO. 21/E/KPT/2018}

jasa menjadi hanya lima dimensi yang disebut SERVQUAL (kualitas jasa) dalam (Tjiptono 2014: 282) yaitu : (1) reliabiliy, (2) responsiveness, (3) Assurance, (4) empathy, (5) Tangible. Usaha jasa pertambangan adalah usaha jasa yang kegiatannya berkaitan dengan tahapan dan/atau bagian kegiatan usaha pertambangan. Usaha jasa pertambangan yang utama dari sisi skala bisnis adalah kontraktor dan jasa pengangkutan. (Rachmat Saleh).

Untuk industri jasa lebih menekankan pada kinerja pelayanan dibandingkan dari kinerja produk/barang yang dijual. Meski memiliki perbedaan sifat marketing mix untuk barang dengan jasa namun secara prinsip memiliki kesamaan karena marketing mix jasa adalah pengembangan dari konsep konvensional. Lovelock menyampaikan variabel-variabel pengembangan dari konvensional marketing mix meliputi 7P yang disebut dengan Integrated Service Management.

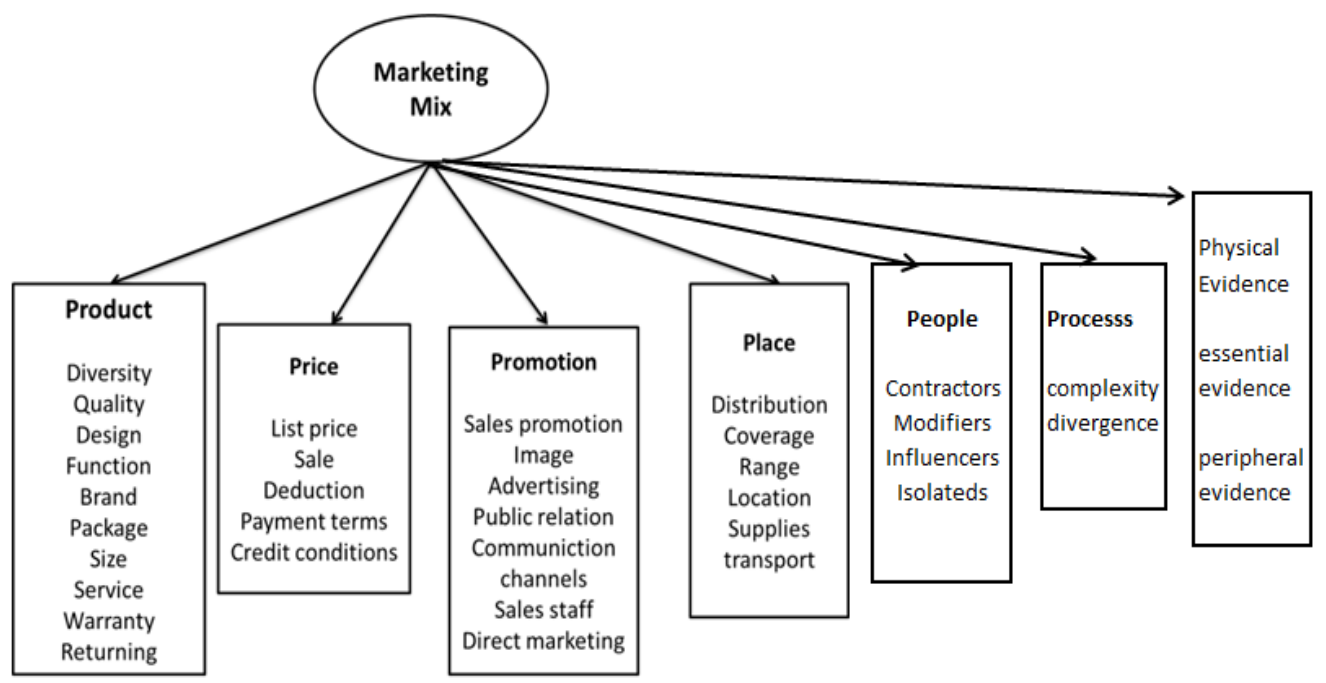

\section{Gambar 2.1. Bauran Pemasaran (Marketing Mix 7P)}

Sumber : Kotler \& Keller (2012) \& Rambat Lupiyoadi-A.Hamdani (edisi 2-2006)

Orang $\left(\mathbf{X}_{2}\right)$. Menurut Zeithaml and Bitner yang dikutif oleh Ratih Hurriyanti (2005:62) “Orang (people) adalah semua pelaku yang memainkan peranan dalam penyajian jasa sehingga dapat mempengaruhi persepsi pembeli Menurut Nirwana (2012) menjelaskan bahwa dimensi people yang kompeten adalah manusia yang memiliki Skill, Education, dan Knowledge. Orang (People) menurut Philip Kotler (2012) yaitu proses seleksi, pelatihan, dan pemotivasian karyawan yang nantinya dapat digunakan sebagai pembeda perusahaan dalam memenuhi kepuasan pelanggan. Pihak perusahaan dalam hal ini di wakili manajemen berperan penting dalam memenuhi kebutuhan pengembangan diri karyawannya sebagai investasi dengan harapan apabila pegawai menjalani peningkatan pendidikan, keterampilan dan kemampuan maka mereka akan lebih berkualitas pekerjaannya dan dapat berkontribusi positif pada kemajuan perusahaan.

Proses $\left(\mathbf{X}_{3}\right)$. Menurut Zeithaml and Bitner yang dikutif oleh Ratih Hurriyati (2005) "Proses adalah semua prosedur aktual, mekanisme, dan aliran aktifitas yang digunakan untuk menyampaikan jasa secara cepat dan tepat dalam memberikan jasa". Menurut Tjiptono (2009) "Proses meliputi prosedur aktual, tugas dan tahap-tahap aktivitas yang dilakukan dalam rangka menghasilkan dan menyampaikan jasa dengan proses penyampaian jasa sederhana, 


\section{NATIONALLY ACCREDITED JOURNAL - DECREE NO. 21/E/KPT/2018}

sehingga mereka bisa menerima layanan jasa tanpa kesulitan berarti". Lovelock dikutif Nirwana (2012) menguraikan beberapa unsur yang terlibat dalam proses jasa yaitu prosedur, tugas, rencana, mekanisme dan arus aktifitas. Dikutip Nirwana dari Lyn Shosstack dalam Adrian Payne bahwa proses merupakan element terstruktur yang dibangun untuk menyampaikan jasa kepada pelanggan. Jadi kinerja merupakan perwujudan adanya suatu proses.

Bukti Fisik $\left(\mathbf{X}_{4}\right)$. Menurut Yazid (2005:20) Bukti fisik adalah lingkungan fisik dimana jasa disampaikan dan dimana perusahaan dan konsumennya berinteraksi serta setiap komponen tangible yang memfasilitasi penampilan yang dipakai untuk berkomunikasi atau mendukung peran jasa tersebut. Adrian Payne (2000:164) menjelaskan Physical evidence merupakan lingkungan fisik perusahaan jasa dimana layanan diciptakan serta dimana penyedia jasa dan konsumen berinteraksi, ditambah unsur-unsur berwujud yang ada dan dipakai untuk berkomunikasi atau mendukung peran jasa. Menurut Zeithaml, Valerie, \& Bitner (2009: 282), bukti fisik adalah dimana jasa disalurkan melalui interaksi dengan pelanggan dan dimana setiap komoditas yang memfasilitasi kinerja dan komunikasi jasa itu sendiri. Mengutip R.Lupiyoadi-A.Hamdani $(2008,89)$ bahwa bukti fisik adalah lingkungan fisik perusahaan tempat jasa di ciptakan dan tempat penyedia jasa dan konsumen berinteraksi, di tambah unsur tangible apa saja yang di gunakan untuk mengkomunikasikan atau mendukung peran jasa itu. Para pemasar jasa perlu menunjukan fisik untuk dimensi intangible jasa yang di tawarkan perusahaannya agar mendukung positioning dan image serta meningkatkan lingkup produk. Mereka membagi bukti fisik pemasaran jasa dalam 2 klasifikasi yaitu: 1. Bukti penting (essential evidence) yang merepresentasikan keputusan kunci yang di buat penyedia jasa misalkan peralatan, bentuk bangunan kantor dan bengkel kerja. Hal ini akan dapat menambah lingkup produk secara signifikan. 2. Bukti tambahan (peripheral evidence) merupakan nilai independen yang realatif kecil tetapi menambah kerberwujudan pada nilai yang di sediakan produk jasa misalkan pemilikan dan penempatan merek di alat-alat kerja, prestasi dan penghargaan, sertifikasi dll. Dari penjelasan teori di atas, penulis mengadopsi teori dari Lupiyoadi-Hamdani untuk di jadikan variabel penelitian.

Keputusan Pembelian (Y). Menurut Schiffman dan Kanuk (2008), sebuah keputusan adalah seleksi terhadap dua pilihan alternatif atau lebih. Pilihan alternatif harus tersedia bagi seseorang ketika mengambil keputusan. Menurut Nugroho (2003) adalah proses pengintegrasian yang mengkombinasi sikap pengetahuan untuk mengevaluasi dua atau lebih perilaku alternatif, dan memilih salah satu diantaranya. Menurut Kotler dan Keller (2012) bahwa keputusan pembelian terdiri dari 5 dimensi yaitu: (1) pengenalan kebutuhan, (2) pencarian informasi, (3) evaluasi alternatif, (4) keputusan pembelian, (5) perilaku pasca pembelian. Model ini mempunyai anggapan bahwa para konsumen melakukan lima tahap dalam melakukan pembelian. Namun Kotler menyatakan bahwa kelima tahap diatas tidak selalu terjadi, khususnya dalam pembelian yang tidak memerlukan keterlibatan yang tinggi dalam pembelian. Para konsumen dapat melewati beberapa tahap dan urutannya tidak sesuai. Dari penjelasan di atas penulis mensistesis variabel yang menjadi topik kajian yaitu (1) pengenalan kebutuhan, (2) pencarian informasi, (3) evaluasi alternatif, (4) keputusan pembelian, (5) perilaku panca pembelian. 


\subsection{Kerangka Berfikir}

1) Terdapat pengaruh positif antara kualitas jasa $\left(X_{1}\right)$ terhadap keputusan pembelian $(Y)$ yang ditunjukkan melalui dimensi reliability (keandalan) < responsiveness (daya tanggap) dan assurance (jaminan dan kepastian). Variabel kualitas jasa ini akan menunjukkan kepada konsumen sejauh mana jasa ini memenuhi spesifikasi yang diharapkan oleh konsumen tersebut. Kemampuan penyedia jasa ini akan sangat menentukan kecenderungan calon konsumen untuk memilih oleh siapa jasa itu diberikan kepadanya. Ketika keandalan yg baik, respon kepada konsumen tepat dan akurat dan jaminan dan kepastian dipenuhi maka calon konsumen akan semakin yakin mengenai siapa pemberi jasa yang akan dia pilih dan akhirnya terjadi suatu transaksi pembelian. Oleh sebab itu kualitas jasa $\left(X_{1}\right)$ yang diberikan oleh calon penyedia jasa akan sangat menentukan kepada keputusan pembelian $(\mathrm{Y})$ dari calon konsumennya.

2) Terdapat pengaruh positif antara elemen manusia $\left(X_{2}\right)$ terhadap keputusan pembelian (Y) sebagai dampak positif pada dimensi skill (keterampilan), education (pendidikan) \& knowledge (pengetahuan). Sumber daya manusia merupakan sumber keunggulan kompetitif yang tak lekang oleh waktu berbeda dengan perkembangan teknologi produk ataupun proses produksi semakin lama akan berkurang keunggulan kompetitifnya seiring waktu. Keterlibatan langsung antara penyedia jasa dan penerima jasa sangat berperan besar atas suksesnya perusahaan ini. Oleh sebab itu semakin baik kompetensi dari pelaku pemberi jasa diikuti keterlibatan yang mendalam dengan pelanggan maka akan semakin besar keberhasilan dari usaha ini. Dengan kata lain kompetensi anggota organisasi $\left(\mathrm{X}_{2}\right)$ semakin tinggi maka semakin memperkuat minat calon konsumen untuk membuat keputusan pembelian $(\mathrm{Y})$ jasanya.

3) Pengaruh proses $\left(X_{3}\right)$ juga akan memberikan sinyal positif terhadap keputusan pembelian (Y). Proses ini merupakan kegiatan dalam mewujudkan jasa. Ia tidak bisa dipisahkan dan sangat erat kaitannya dengan aktivitas dan kinerja. Proses ini merupakan aktivitas penyampaian jasa dan pemenuhan janji yang telah diberikan perusahaan penyedian jasa. Maka proses merupakan rangkaian prosedur, arus aktivitas atau mekanisme penyampaian jasa tersebut. Proses ini untuk memastikan agar penyampaian jasa yang diharapkan oleh konsumen terpenuhi melalui ketersediaan prosedur kerja yang tepat, tugas yang terencana serta aliran pekerjaan yang simultan sehingga jasa yang diberikan berkualitas. Kesesuaian kualitas jasa dengan harapan yang dimiliki konsumen menjadi ukuran dalam menilai. Kesesuaian tersebut diukur dari prosedur yang memadai, perencanaan yang tepat dan akurat, rangkaian aktivitas pekerjaan yang aman dan berkualitas. Semakin baik dimensi tersebut maka akan semakin baik jasa yang disampaikan kepada konsumen dan akan semakin memperkuat keyakinan untuk membuat keputusan pembelian.

4) Pengaruh positif dari variabel bukti fisik $\left(X_{4}\right)$ juga akan memberikan pengaruh yang kuat terhadap keputusan pembelian (Y). Jasa memerlukan tampilan yang mudah dipahami oleh konsumen mengenai keberadaannya. Jasa ini pun tidak bisa dipisahkan dengan fasilitas pendukung secara fisik yang akan mewujudkan target atau janji kepada konsumen. Perusahaan jasa akan memberikan janji/komitmen yang menunjukkan keberadaan mereka dan jenis pekerjaan yang dapat disampaikan serta didukung oleh fasilitas fisik lainnya. Semakin baik fasilitas fisik dan penunjangnya maka akan semakin baik kemampuan perusahaan menyampaikan jasa sebagai 
produknya kepada konsumen. Oleh sebab itu pengaruh bukti fisik terhadap keputusan pembelian akan semakin tinggi apabila bukti fisik dari perusahaan ini semakin baik dan representatif.

5) Pengaruh positif dimiliki antara variabel kualitas jasa $\left(X_{1}\right)$, karyawan kompeten $\left(X_{2}\right)$, proses $\left(X_{3}\right)$ dan bukti fisik (4), dimana masing-masing dimensinya secara bersama-sama mempengaruhi terhadap keputusan pembelian konsumen $(\mathrm{Y})$ yang ditunjukkan dalam dimensi pengenalan kebutuhan, pencarian informasi, evaluasi alternatif, keputusan pembelian, dan perilaku pasca pembelian. Jadi dapat dikatakan bahwa semakin tinggi kualitas jasa $\left(X_{1}\right)$, karyawan berkualitas $\left(X_{2}\right)$, proses $\left(X_{3}\right)$ dan bukti fisik $\left(X_{4}\right)$ maka akan semakin kuat pula keputusan pembelian diarahkan kepada PT BUMA (Y).

Variabel $X$ ditetapkan sebagai variable independen yang terdiri dari :

Kualitas Jasa $\left(X_{1}\right)$, Karyawan $\left(X_{2}\right)$, Proses $\left(X_{3}\right)$ dan Bukti Fisik $\left(X_{4}\right)$. Sedangkan variabel $Y$ sebagai variabel dependen yaitu keputusan pembelian.

Model hubungan antar variabel dan dimensi dapat digambarkan dalam skema di halaman berikut ini.

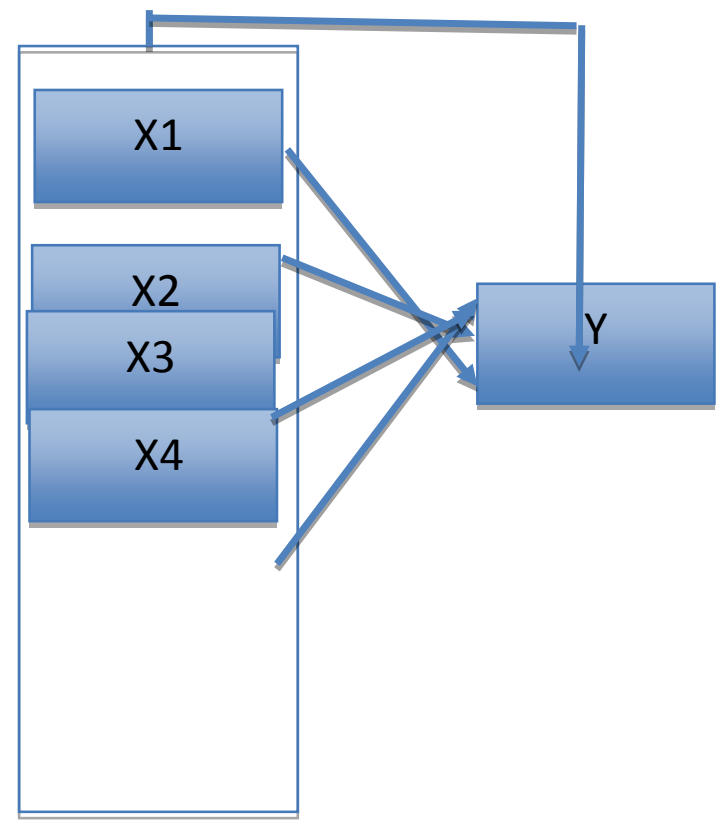

\section{Gambar 2.2. Kerangka Berfikir}

Hipotesis Penelitian

H1: Kualitas jasa berpengaruh terhadap keputusan pembelian jasa penambangan PT BUMA.

$\mathrm{H}_{2}$ : Personel yang kompeten berpengaruh terhadap keputusan pembelian jasa penambangan PT BUMA.

$\mathrm{H}_{3}$ : $\quad$ Proses berpengaruh terhadap keputusan pembelian jasa penambangan PT BUMA.

$\mathrm{H}_{4}$ : Bukti fisik berpengaruh terhadap keputusan pembelian jasa penambangan PT BUMA.

$\mathrm{H}_{5}$ : Kualitas jasa/Produk, Personel, Proses dan bukti fisik secara bersama-sama berpengaruh secara langsung dan positif terhadap keputusan pembelian jasa penambangan PT BUMA. 


\section{NATIONALLY ACCREDITED JOURNAL - DECREE NO. 21/E/KPT/2018}

\section{METODE PENELITIAN}

\subsection{Jenis Penelitian}

Desain penelitian yang digunakan penulis dalam penelitian ini adalah penelitian konklusif, berjenis riset kausal. Selain itu, metode penelitian ini merupakan metode kuantitatif dengan menggunakan metode survei. Menurut Kuncoro (2003) penelitian konklusif atau Confirmatory Research adalah penelitian yang bertujuan untuk menguji atau untuk membuktikan sesuatu dan membantu peneliti dalam memilih tindakan khusus selanjutnya.

\section{Variabel Penelitian/Fenomena Yang Diamati}

a) Kualitas Jasa/(Service Quality) $\left(\mathrm{X}_{1}\right)$

Menurut Kotler dalam Nirwana $(2012,17)$ bahwa jasa adalah suatu manfaat yang di tawarkan satu pihak kepada pihak lainnya. Sedangkan menurut Lovelock bahwa jasa adalah aktivitas yang ditawarkan ke pelanggan yang merupakan aktivitas ekonomi yang mampu menciptakan nilai dan keuntungan bagi pelanggan pada waktu dan tempat yang tepat. Produk jasa yang ditawarkan oleh PT BUMA berupa jasa penambangan dengan rincian pengupasan, pemindahan, pemberaian batuan penutup, penambangan batubara dan transportasinya merupakan jasa yang manfaatnya diharapkan oleh konsumen PT Berau Coal. Konsumen penerima jasa mengharapkan seluruh rangkaian pekerjaan tersebut dapat terlaksana dengan baik dan berkualitas sehingga keluaran dari jasa yang disampaikan dalam bentuk batubara memenuhi kualifikasi yang konsumen tetapkan. Guna memenuhi harapan penyampaian jasa ini maka dimensi kualitas jasa sangat penting untuk bisa dijadikan dasar pengukuran yang terdiri dari 1.) Keandalan, 2.) Ketanggapan dan 3.) Jaminan \& Kepastian.

\section{b) Orang/People $\left(\mathrm{X}_{2}\right)$}

Variabel orang sebagai pelaku dalam penyampaian jasa memiliki peran yang sangat penting agar jasa yang diharapkan oleh konsumen terpenuhi. Guna mencapai target tersebut tentunya karyawan tersebut memiliki kualifikasi yang sesuai dengan kebutuhan. Karyawan yang kompeten haruslah dimiliki oleh perusahaan agar kualitas jasa dapat memenuhi harapan konsumen. Karyawan sebagai anggota organisasi dituntut untuk memiliki pengetahuan, keterampilan mengenai operasional tambang yang efektif dan efisien yang diperoleh dari hasil pendidikan formal baik internal maupun eksternal perusahaan. Penyediaan karyawan kompeten ini dapat diteliti melalui dimensi: 1. pengetahuan/knowledge 2. Pendidikan/Education 3. Keterampilan/Skill.

\section{c) Proses/Process $\left(X_{3}\right)$}

Variabel proses ini adalah pembeda antara pemasaran produk yang berbentuk barang/fisik dibanding pemasaran jasa. Proses ini didefinisikan sebagai rangkaian cara kerja yang standard untuk menjamin tercapainya target produksi. Proses ini merupakan variabel penting dalam perusahaan jasa dan antara pengguna jasa dengan penyedia jasa terlibat dalam perwujudan jasa tersebut (Nirwana, 2012:39). Karena sifatnya yang tidak berwujud itulah sangat penting untuk memastikan dimensi proses ini tersedia dengan baik. Dimensi tersebut meliputi : 1) Prosedur 2) Tugas 3) Rencana 4) Aktivitas kerja. Dimensi-dimensi tersebut merupakan faktor penunjang terselenggaranya penyampaian produk jasa yang sesuai dengan harapan konsumen. 


\section{NATIONALLY ACCREDITED JOURNAL - DECREE NO. 21/E/KPT/2018}

\section{d) Bukti Fisik/Physical evidence $\left(\mathrm{X}_{4}\right)$}

Bukti fisik ini adalah variabel yang penting sebagai sarana untuk menampilkan wajah atau keberadaan dann status jasa tersebut. Keberadaan fisik dari perusahaan tersebut merupakan faktor penting untuk dapat meyakinkan pengguna jasa akan kemampuan dan kualitas penyedia jasa. Selain keberadaan fisik juga penting adanya bukti penunjang yang meski mungkin terkesan sepele namun berpengaruh terhadap niat dan keputusan pembelian. Varibel bukti fisik yang menjadi kajian meliputi : 1.) Bukti penting dan 2.) bukti penunjang.

\section{e) Keputusan Pembelian (Y)}

Adalah variabel yang didefinisikan sebagai pengambilan keputusan terhadap alternatif pilihan yang tersedia sesuai dengan harapan konsumen. Dimensi keputusan pembelian meliputi : (1) pengenalan kebutuhan (2) pencarian informasi (3) evaluasi alternatif (4) keputusan pembelian (5) perilaku pasca pembelian.

Variabel lain yang juga perlu dijadikan bahan kajian sesuai dengan teori marketing mix adalah faktor price, placement dan promotion. Penulis menduga bahwa faktor harga akan sangat berpengaruh signifikan pada keputusan pembelian namun karena faktor confidentiality dan sulitnya mendapatkan akses data yang riil maka variabel ini sulit untuk dilanjutkan. Sedangkan untuk placement dan promotion meski kemungkinan memberikan pengaruh namun asumsi penulis hanya akan memberikan efek minimal karena sifat dari jasa yang dijual bukan untuk konsumsi khalayak umum.

\subsection{Metode Penelitian}

Jenis/Desain Penelitian

Desain penelitian yang digunakan penulis dalam penelitian ini adalah penelitian konklusif, berjenis riset kausal. Selain itu, metode penelitian ini merupakan metode kuantitatif dengan menggunakan metode survei. Menurut Kuncoro (2003) penelitian Konklusif atau Confirmatory Research adalah penelitian yang bertujuan untuk menguji atau untuk membuktikan sesuatu dan membantu peneliti dalam memilih tindakan khusus selanjutnya. Menurut Malhotra (2009) penelitian konklusif bersifat lebih formal dan terstruktur jika dibandingkan dengan penelitian eksploratif. Penelitian ini didasarkan atas sampel besar yang representatif, dan data yang dihasilkan dianalisis secara kuantitatif. Temuan penelitian ini dianggap sebagai kesimpulan dan menjadi masukan bagi pengambilan keputusan manajemen.

Riset Kausal sendiri merupakan riset yang digunakan untuk mendapatkan bukti hubungan sebab akibat (Malhotra, 2009). Kausalitas berarti sesuatu yang sangat berbeda menurut orang awam dibandingkan dengan seorang ilmuwan. Pernyataan seperti $X$ menyebabkan $\mathrm{Y}$ akan mempunyai arti yang berbeda bagi seorang awam dengan seorang ilmuwan. Makna ilmiah kausalitas lebih sesuai dengan riset pemasaran dibandingkan dengan makna yang di pakai sehari-hari. Efek pemasaran disebabkan oleh variabel majemuk dan hubungan antara penyebab dan akibat cenderung bersifat probabilistik. Lebih lagi, kita tidak pernah dapat membuktikan kausalitas (yaitu menunjukkan bukti secara konklusif), namun kita hanya menyimpulkan hubungan sebaab akibat. Dengan kata lain, mungkin saja bahwa hubungan kausal sebenarnya, jika memang ada mungkin tidak dapat diidentifikasi (Malhotra, 2009).

Selain itu, metode survey didefinisikan Kerlinger dalam Sugiyono (2014) sebagai penelitian yang dilakukan pada populasi yang besar maupun kecil, namun data yang 


\section{NATIONALLY ACCREDITED JOURNAL - DECREE NO. 21/E/KPT/2018}

dipelajari adalah sampel dari populasi tersebut, untuk menemukan kejadian-kejadian relatif, distribusi, dan hubungan-hubungan antar-variabel sosiologis maupun psikologis.

Penelitian ini adalah penelitian untuk mengetahui pengaruh satu atau lebih variabel bebas (independent variabel) terhadap variabel terikat (dependent variabel) dengan memerlukan pengujian hipotesis dengan uji statistik. Dalam hal ini untuk mengetahui pengaruh sebagian dari bauran pemasaran terhadap kepuasan pelanggan jasa penambangan batubara dengan pengujian statistik guna mengetahui apakah product, process, people $\mathcal{E}$ Physical evidence mempunyai pengaruh yang signifikan terhadap keputusan pembelian tersebut.

\subsection{Definisi Operasional}

Dalam penggunaan metode penelitian ini, penulis membatasi lingkup penelitian hanya 5 variabel. Ke lima variabel di bawah ini merupakan sistesis teori yg di buat penulis berdasarkan teori yang dievaluasi dan di anggap sesuai yaitu:

Variabel $\mathrm{X}_{1}$ : produk (berupa kualitas jasa) yang memiliki dimensi berupa: reliability produksi overburden dan batubara (keandalan), responsiveness pada proses penambangan (daya tanggap), Assurance terhadap jadwal dan kualitas produk penambangan (Jaminan)

Variable $\mathrm{X}_{2}$ : Orang yang memiliki dimensi berupa Education, knowledge dan Skill

Variabel $X_{3}$ : Proses yang memiliki dimensi berupa prosedur, tugas, rencana dan arus aktifitas.

Variable $\mathrm{X}_{4} \quad$ : Bukti fisik berupa bukti penting dan bukti tambahan dan

Variabel Y : Keputusan pembelian berupa dengan dimensi:Pengenalan kebutuhan, Pencarian informasi, Evaluasi alternatif, Keputusan pembelian, dan Perilaku pasca pembelian

Penelitian ini di lakukan di perusahaan PT Bukitmakmur Mandiri Utama dengan lokasi project di area Lati Mine Operation - PT Berau Coal.

\subsection{Instrumen Penelitian}

Instrumen penelitian diturunkan dari definisi operasional masing-masing variabel.

Definisi operasioanal terdiri dari konsep variabel, dimensi dan indikator. Dari definisi operasional diturun instrumen penelitian sebagaimana tabeldibawah ini. 


\section{NATIONALLY ACCREDITED JOURNAL - DECREE NO. 21/E/KPT/2018}

Tabel 3.1. Kisi-Kisi Instrumen Penelitian

\begin{tabular}{|c|c|c|c|c|}
\hline Variabel & Dimensi & & Indikator & Skor \\
\hline \multirow{7}{*}{ Kualitas Jasa } & \multirow{3}{*}{ X1.1 Reliabilitas } & 1.1 .1 & $\begin{array}{l}\text { Mampu melakukan pengupasan, penuatan dan pemindahan batuan } \\
\text { penutup }\end{array}$ & \multirow{7}{*}{ skala Likert } \\
\hline & & 1.1 .2 & Mampu melakukan pemberaian batuan penutup & \\
\hline & & 1.1 .3 & Mampu melakukan pengangkutan batuan penutup juga batubara & \\
\hline & \multirow[t]{2}{*}{ X1.2 Responsiveness } & 1.2 .1 & Mampu merespon keinginan konsumen dengan tepat dan cepat & \\
\hline & & 1.2 .2 & Mampu menyelesaikan masalah yang menjadi perhatian konsumen & \\
\hline & \multirow[t]{2}{*}{ X1.3 Assurance } & 1.3 .1 & Tersedia perahtan dan teknologi penambangan yang memadai & \\
\hline & & 1.3 .2 & Organisasi BUMA meyakinkan dan mampu memenuhi komitmen. & \\
\hline \multirow{6}{*}{ Orang } & \multirow[b]{2}{*}{$\begin{array}{l}\text { X2.1 Pengetahuan/ } \\
\text { Knowledge }\end{array}$} & 2.1 .1 & Memilikipengahman sehngga mampu berfikir cepat & \multirow{6}{*}{ skala Likert } \\
\hline & & 2.1 .2 & $\begin{array}{l}\text { Penguasaan pekerjaan yg cukup/Memiliki pengalaman dalam bertindak } \\
\text { tepat }\end{array}$ & \\
\hline & \multirow{2}{*}{$\begin{array}{l}\text { X2.2 Pendidikan } \\
\text { Education }\end{array}$} & 2.2 .1 & Memillki strata pendidikan formal minmum sesuai jabatan & \\
\hline & & 2.2 .2 & Memiliki lembaga pelatihan formal dahm organsasi. & \\
\hline & \multirow[b]{2}{*}{$\begin{array}{l}\text { X2.3 Keterampilan/ } \\
\text { Skill }\end{array}$} & 2.3 .1 & Terampil menyeksaikan tugas dan tanggung jawab & \\
\hline & & 2.3 .2 & $\begin{array}{l}\text { Terampil memilh cara kerja/SOP paling tepat dahm menyelesaikan } \\
\text { pekerjaan }\end{array}$ & \\
\hline \multirow{8}{*}{ Proses } & \multirow[t]{2}{*}{ X3.1. Prosedur } & 3.1 .1 & Prosedur mencukupi untuk pekerjaan penyampaian jasa & \multirow{8}{*}{ skala Likert } \\
\hline & & 3.1 .2 & Prosedur mudah di akses dan di distribusi ke semua stakeholder & \\
\hline & \multirow[t]{2}{*}{ X3.2. Tugas } & 3.2 .1 & Terdapat struktur kerja organisasi yang jelas & \\
\hline & & 3.2 .2 & Pembagian rangkaian pekerjaan dan handover yang jelas & \\
\hline & \multirow[t]{2}{*}{ X3.3 Rencana } & 3.3 .1 & Rencana kerja tersedia dan disetujui konsumen & \\
\hline & & 3.3 .2 & Evaluasi capaian rencana kerja. & \\
\hline & \multirow[t]{2}{*}{ X3.4 Arus aktifitas } & 3.4 .1 & $\begin{array}{l}\text { Operator menjalankan proses produksi dengan a lat-a lat kerja } \\
\text { penambangan }\end{array}$ & \\
\hline & & 3.4 .2 & Manajemen mengelola seluruh operasi penambangan dan pelaporan & \\
\hline \multirow{6}{*}{ BuktiFisik } & \multirow[t]{3}{*}{ X4.1 Penting/Esential } & 4.1 .1 & Kualitas alat-alat berat sebagai alat utama pekerjaan & \multirow{6}{*}{ skala Likert } \\
\hline & & 4.1 .2 & Kualitas fasilitas workshop & \\
\hline & & 4.1 .3 & Kualitas fasilitas kantor tambang & \\
\hline & \multirow[t]{3}{*}{ X4.2 Tambahan } & 4.2 .1 & Fasilitas mess karyawan & \\
\hline & & 4.2 .2 & Fasilitas transportasi (LV, bus man haul dII) & \\
\hline & & 4.2 .3 & Tampilan karyawan berupa seragam, logo perusahaan dll & \\
\hline \multirow{8}{*}{$\begin{array}{l}\text { Keputusan } \\
\text { pembelian }\end{array}$} & $\begin{array}{l}\text { Y1.Pengenalan } \\
\text { Kebutulan }\end{array}$ & 5.1 .1 & Kebutuhan partner kerja strategis & \multirow{8}{*}{ skala Likert } \\
\hline & Y2. Pencarian Informasi & 5.2 .1 & $\begin{array}{l}\text { Penggalian informasi internal \& eksternal PT BC terhadap calon penyedia } \\
\text { jasa }\end{array}$ & \\
\hline & Y3. Evaluasi Alternatif & 5.3 .1 & Evaltasi profil calon penyedia jasa & \\
\hline & \multirow{3}{*}{$\begin{array}{l}\text { Y4. Keputusan } \\
\text { Pembelian }\end{array}$} & 5.4 .1 & Penumiukan dan penetapan pemenang tender & \\
\hline & & 5.4 .2 & penetapan lingkup keria & \\
\hline & & 5.4 .3 & Penetapan durasi kerjasama & \\
\hline & \multirow{2}{*}{$\begin{array}{l}\text { Y5. Perilaku Pasca } \\
\text { Pembelian }\end{array}$} & 5.5 .1 & Konsumen puas dengan jasa yang di terima & \\
\hline & & 5.5 .2 & Melakukan evaluasi dan feedback & \\
\hline
\end{tabular}

\subsection{Uji Validitas}

Menurut Priyatno (2010:90) Uji Validitas item digunakan untuk mengukur ketepatan suatu item dalam kuezioner atau skala, apakah item-item kuezioner tersebut sudah tepat dalam mengukur apa yang ingin diukur. Seluruh indikator pada semua variabel penelitian menghasilkan nilai lebih besar dari $r$ tabel sehingga dengan demikian dapat dikatakan bahwa item-item pertanyaan yang mengukur setiap variabel penelitian dapat dinyatakan valid.dari sejumlah butir instrument yang diujicobakan ternyata semmuanya valit atau tidak ada yang gugur. 


\subsection{Uji Reliabilitas}

Menurut Priyatno, (2010:97) Uji reliabilitas digunakan untuk mengetahui adanya konsistensi alat ukur, apakah alat pengukur yang digunakan dapat diandalkan dan tetap konsisten jika pengukuran tersebut diulang. Diketahui bahwa besarnya nilai cronbach's alpha pada setiap variabel penelitian nilainya secara umum lebih besar dari 0.75 sehingga secara jelas lebih besar dari 0.60. merujuk ke definisi Arikunto, bahwa nilai reliabilitas di atas 0.7 adalah berkategori reliabilitas yang tinggi. Dengan demikian pertanyaan dari variable diatas tersebut dapat dinyatakan memenuhi syarat reliabilitas. Dari 5 (lima) varial penelitian denga sejumlah butir intrumen ternya semua reliabel.

\subsection{Jenis dan Sumber Data}

Data yang digunakan dalam penelitian ini adalah data primer dan data sekunder.

1. Data primer adalah data yang dibuat oleh peneliti untuk maksud khusus menyelesaikan masalah riset (Malhotra, 2005). Data primer dalam penelitian ini adalah data yang diperoleh secara langsung menggunakan kuisioner kepada responden/konsumen sebagai sumber informasi.

2. Data sekunder adalah data yang telah dikumpulkan untuk maksud selain untuk menyelesaikan masalah yang dihadapi (Malhotra, 2005). Data sekunder yang di gunakan di penelitan ini adalah data yang diperoleh dari literatur, studi pustaka dan sumber lainnya sebagai informasi pendukung penelitian ini.

\subsection{Populasi dan sample}

Menurut Malhotra (Malhotra K. Naresh. 1993. Marketing Research An Applied Orientation, second edition, Prentice Hall International Inc, New Jersey, p. 364) sampel adalah sub-kelompok populasi yang dipilih untuk berpartisipasi dalam studi. Karakteristik sampel disebut statistik, kemudian dipakai untuk membuat inferensi (kesimpulan) mengenai parameter populasi. Di sisi lain Sugiyono (Metode Penelitian Manajemen, 2014, hal. 149) menjelaskan, sampel adalah bagian dari jumlah dan karakteristik yang dimiliki oleh populasi tersebut. Dari populasi yang dapat di survey berjumlah sekitar 100 orang, maka dengan menggunakan persamaan Slovin dan menetapkan derajat kesalahan sebesar $10 \%$ (Savella, Cosnsuelo, et al 2007), di dapat bahwa sample yang dapat di ambil adalah sejumlah 50 orang dari berbagai tingkat jabatan dan jenis pekerjaan.

\subsection{Teknik Penarikan Sampel}

Metode sampling yang digunakan oleh peneliti adalah metode non-probabilitas. Menurut Malhotra (2009:372) metode ini mengandalkan judgement pribadi peneliti daripada peluang untuk memilih elemen sampel. Peneliti dapat secara sembarang atau secara sadar memutuskan elemen apa yang akan dimasukkan kedalam sampel. Sampel non-probabilitas dapat menghasilkan perkiraan yang bagus mengenai karakteristik populasi. Menurut Sugiyono (2014:154) non-probability sampling methods ini merupakan pengambilan sampel yang tidak semua member mendapatkan peluang/ kesempatan sama bagi setiap unsur atau anggota populasi. 


\section{NATIONALLY ACCREDITED JOURNAL - DECREE NO. 21/E/KPT/2018}

\subsection{Jenis dan Sumber Data}

Data yang digunakan dalam penelitian ini adalah data primer dan data sekunder.

Data primer adalah data yang dibuat oleh peneliti untuk maksud khusus menyelesaikan masalah riset (Malhotra, 2005). Data primer dalam penelitian ini adalah data yang diperoleh secara langsung menggunakan kuisioner kepada responden/konsumen sebagai sumber informasi.

Data sekunder adalah data yang telah dikumpulkan untuk maksud selain untuk menyelesaikan masalah yang dihadapi (Malhotra, 2005). Data sekunder yang di gunakan di penelitan ini adalah data yang diperoleh dari literatur, studi pustaka dan sumber lainnya sebagai informasi pendukung penelitian ini.

\subsection{Teknik Analisis Data}

\section{Analisis Statitik Deskriptif}

Statistika deskriptif adalah bagian dari statistika yang mempelajari alat, teknik, atau prosedur yang digunakan untuk menggambarkan atau mendeskripsikan kumpulan data atau hasil pengamatan yang telah dilakukan. Kegiatan - kegiatan tersebut antara lain adalah kegiatan pengumpulan data, pengelompokkan data, penentuan nilai dan fungsi statistik, serta pembuatan grafik, diagram dan gambar. Analisi deskriptip yang digunakan adalah Mean, Median dan Modus.

\section{Uji Asumsi klasik}

Persyaratan untuk bisa menggunakan persamaan regresi linear berganda adalah terpenuhinya uji asumsi klasik. Uji klasik yang umum dipakai yaitu: uji normalitas, uji multikoliniearitas, uji heteroskedastisitas(1)Uji multikolinieritas. Uji ini bertujuan untuk menguji apakah model regresi ditemukan adanya korelasi antar variabel bebas (independen). Jika nilai VIF < 10, maka tidak terjadi multikolinearitas, sebaliknya jika nilai VIF > 10 maka terjadi multikolinearitas. (2) Uji normalitas menurut Priyatno (2010:71) digunakan untuk mengetahui apakah populasi data berdistribusi normal atau tidak. Uji ini biasanya digunakan untuk mengukur data berskala ordinal, interval, ataupun rasio.(3) Uji multikolinearitas adalah keadaan di mana ada hubungan linear secara sempurna atau mendekati sempurna antara variabel independen dalam model regresi.

\section{Uji Regresi Berganda.}

Penelitian ini menggunakan pengolahan data dengan menggunakan Multiple Regression Analysis. Menurut Hair, et al (2010), Analisis regresi majemuk ini merupakan teknik statistika umum yang digunakan untuk menganalisis hubungan antara satu variabel terikat dengan beberapa variabel bebas. Asumsi analisis regresi majemuk ini diantaranya: hubungan antar variabelnya bersifat linear dan distribusinya bersifat normal. Persamaan regresi majemuk atau multiple regression analysis adalah seperti berikut:

$$
\begin{aligned}
& Y=b_{1} X_{1}+b_{2} X_{2}+\ldots \ldots+b n X n+c+e \\
& \text { Dimana: } \\
& Y=\text { variabel yang ingin diprediksi } \\
& b=\text { koefisien regresi } \\
& c=\text { konstanta }
\end{aligned}
$$


$\mathrm{e}=$ error residual

\section{HASIL DAN PEMBAHASAN}

\subsection{Analisis Statistik Deskriptif}

Nilai rata-rata dari setiap variabel yang di dapat dari survei dengan mengunakan skala Likert di dapat bahwa nilai niai di atas 4 yang berarti baik dan sangat baik terhadap PT BUMA. Dapat di lihat pada table di halaman berikut :

Tabel 4.1. Rerata Variabel Bebas dan Terikat

\begin{tabular}{lccccc}
\hline \multicolumn{1}{c}{ Variabel } & N & $\begin{array}{c}\text { Minim } \\
\text { um }\end{array}$ & $\begin{array}{c}\text { Maxim } \\
\text { um }\end{array}$ & Mean & $\begin{array}{c}\text { Std. } \\
\text { Deviation }\end{array}$ \\
\hline Kualitas Jasa $\left(\mathrm{X}_{1}\right)$ & 50 & 3.14 & 5.00 & 4.2972 & 0.51338 \\
Orang $\left(\mathrm{X}_{2}\right)$ & 50 & 2.83 & 5.00 & 4.2566 & 0.56418 \\
Proses $\left(\mathrm{X}_{3}\right)$ & 50 & 3.38 & 5.00 & 4.3376 & 0.44195 \\
Bukti Fisik $\left(\mathrm{X}_{4}\right)$ & 50 & 2.83 & 5.00 & 4.3164 & 0.47357 \\
Keputusan Pembelian & 50 & 3.25 & 5.00 & 4.1996 & 0.42415 \\
$(\mathrm{Y})$ & & & & & \\
Valid N (listwise) & 50 & & & & \\
\hline
\end{tabular}

Dari mean setiap variable di atas menunjukkan bahwa kualitas jasa adalah baik, people adalah baik, bukti fisik adalah baik, demikian juga halnya keputusan pembelian adalah baik.

\subsection{Uji Asumsi Klasik}

Uji asumsi klasik ini dilakukan untuk memperoleh model regresi yang menghasilkan estimator linear yang terbaik.

Normalitas

Berdasarkan plot grafik terlihat bahwa penyebaran titik-titik data yang menyebar searah dengan garis diagonal. Jadi dapat dikatakan bahwa data tersebut berdistribusi normal

\subsection{Uji Multikolinearitas}

Dari hasil uji ini terlihat bahwa nilai VIF tidak lebih dari 10 dan nilai tolerance juga tidak kurang dari 0,1. Maka selanjutnya dapat dinyatakan bahwa model regresi linear berganda ini terbebas dari uji multikolinearistik yaitu tidak terdapat korelasi antar variabel independen dan dapat digunakan dalam penelitian.

\subsection{Uji Heterokedastisitas}

Dari hasil plotting data pada grafik di dapat bahwa tidak terjadi sebuah pola khusus yang terbentuk sehingga ini dapat di katakan bahwa tidak terjadi heteroskedatisitas.

\subsection{Analisis Regresi Linear Berganda.}

Berikut ini adalah hasil pengolahan data menggunakan analisa regresi linear berganda untuk mengetahui hubungan, kualitas jasa, orang, proses dan bukti fisik terhadap keputusan pembelian jasa penambangan oleh PT Berau Coal kepada PT BUMA. Pengolahan data menggunakan program SPSS 20. Hasilnya dapat di lihat pada table 4.2. sebagai berikut : 


\section{NATIONALLY ACCREDITED JOURNAL - DECREE NO. 21/E/KPT/2018}

\begin{tabular}{ccccc}
\multicolumn{5}{c}{ Tabel 4.2. Model Summary } \\
\hline Model & $R$ & $R$ Square & $\begin{array}{c}\text { Adjusted } R \\
\text { Square }\end{array}$ & $\begin{array}{c}\text { Std. Error of the } \\
\text { Estimate }\end{array}$ \\
\hline 1 & $0.833^{a}$ & 0.694 & 0.667 & 0.24465 \\
\hline
\end{tabular}

Koefisien determinan $\left(\mathrm{R}^{2}\right)$ menggambarkan pengaruh varibel kualitas pelayan $(\mathrm{X} 1)$, proses, $(\mathrm{X} 2)$, people $(\mathrm{X} 3)$, bukti fisik $(\mathrm{X} 4)$ terhadap keputusan pembelian $(\mathrm{Y})$ sebesar 0,694 atau 69,4 \% kepusan pembelian dapat dijelaskan oleh variabel kualitas pelayanan, proses, people, dan bukti fisik. Selebih (30,60\% dijelakan oleh faktor lain.

Berdasarkan tabel 3 terlihat bahwa nilai adjusted $\mathrm{R}^{2}$ sebesar 0,694. Jika dilihat dari nilai $\mathrm{R}$ square, terlihat bahwa berarti hubungan variabel kualitas jasa, orang, proses, bukti fisik dengan variabel terikat (Y) keputusan pembelian adalah sebesar 69,4\%, dan sisanya 30,6\% dipengaruhi oleh variabel lain yang tidak dibahas dalam penelitian ini.

\subsection{Uji Statistik $t$}

Pengujian statistik $\mathrm{t}$ ini digunakan untuk mengetahui apakah terdapat pengaruh secara parsial antara kualitas jasa, orang, proses dan bukti fisik terhadap keputusan pembelian. Dalam pengujian ini jika $\mathrm{t}_{\text {hitung }}>\mathrm{t}$ tabel, maka ini berarti terdapat pengaruh yang signifikan secara statistik antara variabel independen tersebut terhadap variabel dependen. Dengan ketentuan jika $t$ hitung $>t$ tabel dan nilai signifikansi $<0.05(a=5 \%)$, maka dikatakan bahwa variabel bebas secara parsial berpengaruh signifikan terhadap variabel terikat. Berikut ini adalah hasil Uji $t$ dari hasil pengolahan data sebagai berikut :

Tabel 4.3 Nilai T Hitung

\begin{tabular}{|c|c|c|c|c|c|c|c|}
\hline \multicolumn{8}{|c|}{ Coefficients } \\
\hline & \multicolumn{2}{|c|}{$\begin{array}{c}\text { Unstandardized } \\
\text { Coefficients }\end{array}$} & \multirow{2}{*}{$\begin{array}{c}\begin{array}{c}\text { Standardized } \\
\text { Coefficients }\end{array} \\
\text { Beta }\end{array}$} & \multirow[b]{2}{*}{$\mathrm{T}$} & \multirow[b]{2}{*}{ Sig. } & \multicolumn{2}{|c|}{$\begin{array}{c}\text { Collinearity } \\
\text { Statistics }\end{array}$} \\
\hline & B & $\begin{array}{l}\text { Std. } \\
\text { Error }\end{array}$ & & & & Tolerance & VIF \\
\hline (Constant) & 0.126 & 0.429 & & 0.293 & 0.771 & & \\
\hline $\begin{array}{l}\text { Kualitas } \\
\text { Jasa }\end{array}$ & 0.250 & 0.078 & 0.303 & 3.191 & 0.003 & 0.755 & $\begin{array}{c}1.32 \\
4\end{array}$ \\
\hline Orang & 0.192 & 0.082 & 0.255 & 2.341 & 0.024 & 0.572 & $\begin{array}{c}1.74 \\
8\end{array}$ \\
\hline Proses & 0.209 & 0.087 & 0.217 & 2.400 & 0.021 & 0.828 & $\begin{array}{c}1.20 \\
7\end{array}$ \\
\hline Bukti Fisik & 0.296 & 0.106 & 0.331 & 2.797 & 0.008 & 0.486 & $\begin{array}{c}2.05 \\
9\end{array}$ \\
\hline
\end{tabular}

Berdasarkan tabel 4 diatas, dapat dibentuk persamaan regresi sebagai berikut:

$$
Y=0.126+0.250 X_{1}+0.192 X_{2}+0.209 X_{3}+0.296 X_{4}
$$

Hasil uji $t$ untuk variabel kualitas jasa terhadap keputusan pembelian jasa penambangan PT Berau Coal, menghasilkan $\mathrm{t}$ hitung sebesar 3.191 lebih besar dari $\mathrm{t}$ table $=$ 2,015 yang berarti kualitas jasa berpengaruh positif terhadap keputusan pembelian jasa 


\section{NATIONALLY ACCREDITED JOURNAL - DECREE NO. 21/E/KPT/2018}

penambangan ini. Semakin baik kualitas jasa BUMA maka akan semakin kuat keyakinan dalam keputusan pembelian jasa ini.

Hasil uji t untuk variabel orang terhadap keputusan pembelian jasa penambangan PT Berau Coal, menghasilkan $\mathrm{t}$ hitung sebesar 2.341 dan lebih besar dari $\mathrm{t}$ table $=2,015$ yang berarti orang dalam organisasi BUMA berpengaruh positif terhadap keputusan pembelian jasa penambangan ini. Semakin baik orang-orang BUMA maka akan semakin kuat keyakinan dalam keputusan pembelian jasa ini.

Hasil uji $t$ untuk variabel proses terhadap keputusan pembelian jasa penambangan PT Berau Coal, menghasilkan $t$ hitung sebesar 2.400 lebih besar dari $t$ table = 2,015 yang berarti proses dalam organisasi BUMA berpengaruh positif terhadap keputusan pembelian jasa penambangan ini. Semakin baik proses yang di jalankan BUMA maka akan semakin kuat keyakinan dalam keputusan pembelian jasa ini.

Hasil uji t untuk variabel bukti fisik terhadap keputusan pembelian jasa penambangan PT Berau Coal, menghasilkan t hitung sebesar 2.797 dan lebih besar dari $\mathrm{t}$ table = 2,015 yang berarti bukti fisiik dalam organisasi BUMA berpengaruh positif terhadap keputusan pembelian jasa penambangan ini. Semakin baik bukti fisik yang dimiliki BUMA maka akan semakin kuat keyakinan dalam keputusan pembelian jasa ini. Dilihat dari nilai beta, variabel yang paling dominan mempengaruhi keputusan pembelian jasa penambangan oleh PT Berau Coal adalah kualitas jasa dimana nilai koefisien beta sebesar 3.191 yang merupakan nilai tertinggi

Uji F.

Uji F digunaka untuk mengetahui pengaruh secara simultan (bersama-sama) variabel independen terhadap variabel dependen digunakan uji F. Dengan ketentuan jika $F_{\text {hitung }}>F_{\text {tabel }}$ dan nilai signifikansi $<0.05(a=5 \%)$, maka variabel bebas secara simultan berpengaruh signifikan terhadap variabel terikat. Berikut ini adalah hasil Uji F dari hasil pengolahan data:

Tabel 4.4. Hasil Uji F

\begin{tabular}{lrrrrr}
\hline \multicolumn{1}{c}{ Model } & $\begin{array}{c}\text { Sum of } \\
\text { squares }\end{array}$ & Df & $\begin{array}{l}\text { Mean } \\
\text { Square }\end{array}$ & $F$ & Sig \\
\hline Regression & 6.122 & 4 & 1.530 & 25.569 & 0.000 \\
Residual & 2.694 & 45 & 0.060 & & \\
Total & 8.815 & 49 & & & \\
\hline
\end{tabular}

Berdasarkan Tabel 5 diatas memperlihatkan nilai $\mathrm{F}$ hitung adalah 25,569 dengan tingkat signifikansi 0,000 , sedangkan $\mathrm{F}$ tabel 2,58 . Oleh karena pada kedua perhitungan yaitu $\mathrm{F}$ hitung $>\mathrm{F}$ tabel $(25,569>2,58)$ dan tingkat signifikansi $(0.000)<0.05$, maka dapat diartikan hipotesis $\mathrm{Ha}$ diterima dan $\mathrm{H}_{0}$ ditolak. Sehingga dapat disimpulkan, bahwa variabel bebas yaitu variabel kualitas jasa $\left(X_{1}\right)$, orang $\left(X_{2}\right)$, proses $\left(X_{3}\right)$, dan bukti fisik $\left(X_{4}\right)$ secara bersama-sama berpengaruh terhadap variabel terikat keputusan pembelian $(\mathrm{Y})$

\section{PENUTUP}

\subsection{Kesimpulan}

Berdasarkan hasil yang didapatkan melalui penelitian mengenai analisa pengaruh variable kualitas jasa penambangan, orang, proses, bukti fisik terhadap keputusan pembelian jasa penambangan batubara oleh PT Berau Coal maka dapat di tarik beberapa 


\section{NATIONALLY ACCREDITED JOURNAL - DECREE NO. 21/E/KPT/2018}

kesimpulan:Nilai rata-rata dari survey yang dilakukan pada variable yang di teliti di dapatkan semuanya bernilai di atas 4 . Hal ini menunjukan bahwa responden memandang baik dan sangat baik terhadap BUMA sebagai sebuah kontraktor tambang batubara.

Dari hasil uji t di dapat:

Variabel kualitas jasa memiliki pengaruh signifikan dengan memiliki nilai signifikansi sebesar $0.003<0.05$ sehingga secara parsial variabel independen kualitas jasa ini berpengaruh signifikan terhadap variabel dependen yaitu keputusan pembelian jasa penambangan oleh PT Berau Coal.

Variabel orang-orang BUMA memiliki pengaruh signifikan dengan memiliki nilai signifikansi sebesar $0.024<0.05$ sehingga secara parsial variabel independen orang/pelaku dalam organisasi ini berpengaruh signifikan terhadap variabel dependen yaitu keputusan pembelian jasa penambangan oleh PT Berau Coal.

Variabel proses memiliki pengaruh signifikan dengan memiliki nilai signifikansi sebesar 0.021 $<0.05$ sehingga secara parsial variabel independen proses dalam perusahaan BUMA ini berpengaruh signifikan terhadap variabel dependen yaitu keputusan pembelian jasa penambangan oleh PT Berau CoalVariabel bukti fisik memiliki pengaruh signifikan dengan memiliki nilai signifikansi sebesar $0.008<0.05$ sehingga secara parsial variabel independen bukti fisik yang di miliki BUMA ini berpengaruh signifikan terhadap variabel dependen yaitu keputusan pembelian jasa penambangan oleh PT Berau Coal.Uji F, secara bersama-sama variable kualitas jasa, orang, proses dan bukti fisik berpengaruh positif dalam keputusan pembelian jasa penambangan oleh PT Berau Coal dengan signifikansi $0.000<0.05$.

\subsection{Saran}

Dari kesimpulan di atas, penulis dapat memberikan saran sebagai berikut:

1. Perusahaan penyedia jasa penambangan seperti BUMA harus memastikan bahwa output dari kualitas jasa ini harus terwujud secara nyata dan di rasakan oleh konsumen. Bentuk nyata kualitas tersebut dapat berupa ketercapaian produksi yang telah di tetapkan, kualitas produk yg sesuai spesifikasi, optimalisasi biaya penambangan dll.

2. Komponen orang-orang BUMA yang kompetitif harus bisa di maksimalkan dalam menjalankan tugas dan tanggung jawab organisasi secara efektif dan efisien. Program pengembangan individu BUMA di setiap level dalam hal pengetahuan, keterampilan dan pendidikan harus terus berjalan serta di tingkatkan seiring dengan perubahan teknologi yang di terapkan di area kerja masing-masing. Disarankan peningkatan kompetensi teknologi akan meningkatkan daya saing personel dan perusahaan.

3. Faktor proses memiliki pengaruh yang sedang terhadap keputusan pembelian, oleh karena itu komponen proses untuk di pastikan memiliki standard yang baik agar pekerjaan jasa yang di sampaikan hasilnya sesuai dengan rencana yang disepakati kedua belah pihak. Saran yang dapat di lakukan perusahaan adalah memperkuat sistem prosedur, Mine plan, arus aktifiitas kerja harus tepat dan akurat sesuai kondisi operasional sehingga efektif dan efisien ketika truck, excavator, dan alat kerja lainnya beraktifitas.

4. Faktor bukti fisik memiliki pengaruh yang signifikan/kuat terhadap keputusan pembelian, oleh karena itu bukti fisik selain secara image memberikan nilai kebanggaan namun juga berkontribusi pada pekerjaan yang di hasilkan. Dengan fasilitas yang memadai maka operasional pekerjaan jasa akan tersampaikan sesuai dengan komitmen kerja yang di sepakati di awal. 


\section{DAFTAR PUSTAKA}

Kotler, Philip \& Keller KL. Manajemen Pemasaran. Jilid 1. Edisi Ketigabelas. Erlanga. Jakarta

Kotler, Philip \& Keller KL. Manajemen Pemasaran. Jilid 2. Edisi Keduabelas. PT Macanan Jaya Cemerlang

Tjipto, Fandy, 2000.Strategi Pemasaran. Penerbit Andi Yogyakarta.

Tjiptono, Fandy. 2007. Pemasaran Jasa. Bayumedia Publishing. Malang.

Tjiptono, Fandy. 2012 Pemasaran Jasa, Prinsip, Penerapan dan Penelitian.

Tjiptono, Fandy. 2012 Service Management. Mewujudkan Layanan Prima, Edisi 2. ANDI Yogyakarta.

Lupiyoadi R., Hamdani A., Manajemen Pemasaran Jasa. Edisi 2.Salemba Empat, Jakarta

Nirwana, 2012. Pemasaran Jasa. Cetakan Pertama, Alta Pustaka, Malang

Dewan Energi Nasional. 2014. Outlook Enegi Indonesia 2014. Biro Fasilitasi Kebijakan Energi dan Persidangan. Sekretariat Jenderal Dewan Energi Nasional. Jakarta.

Dewan Energi Nasional. 2016. Outlook Energi Indonesia 2014. Biro Fasilitasi Kebijakan Energi dan Persidangan. Sekretariat Jenderal Dewan Energi Nasional. Jakarta

Saleh, Rahmat. 2015. Mengenal Usaha Jasa Pertambangan Batubara. http://www.pusdiklatminerba.esdm.go.id/index.php. (diakses tgl 27 Oktober 2016)

UU no. 4 tahun 2009. Pertambangan Mineral Dan Batubara Republik Indonesia.

Peraturan Menteri Energi dan Sumber Daya Mineral, 2012. Perubahan atas Peraturan Menteri Energi dan Sumber Daya Mineral nomor 28 tahun 2009 tentang Penyelenggaraan Usaha Jasa Pertambangan Mineral dan Batubara.

Kementrian Energi dan Sumber daya Mineral. 2015. Statistik Mineral Dan Batubara 2015. Jakarta.

Berau Coal Energy, PT. 2010-2014. Laporan Tahunan Perusahaan. Kantor Pusat. Jakarta.

Delta Dunia Makmur, PT. 2014. Laporan Tahunan Perusahaan. Kantor Pusat. Jakarta.

Ratminto \& Winarsih, Atik. Manajemen Pelayanan. Pustaka Pelajar. Yogyakarta

Diposumarto, Ngadino Surip. 2012. Metodologi Penelitian Teori dan Terapan. Mitra Wacana Media. Jakarta.

Hurriyati, Ratih. 2008. Bauran Pemasaran dan Loyalitas Konsumen. CV. Alfabeta. Bandung.

Istijanto. 2009. Aplikasi Praktis Riset Pemasaran. Gramedia Pustaka Utama. Jakarta.

Kotler, Philip dan Keller, Kevin Lane. 2012. Marketing Management. 14th edition. Pearson Education, Inc. New Jersey.

Kotler, Philip dan Gary Armstrong. 2012. Principles of Marketing. Global Edition. 14th edition . Prentice Hall. New Jersey.

Lovelock, Christoper, Jochen Wirtz dan Jacky Mussry. 2012. Pemasaran Jasa Manusia, Teknologi, Strategi. Jilid I. Edisi ke tujuh. Erlangga. Jakarta

Malhotra, Naresh K., dan Birks, David F. 2009. Marketing Research An Applied Approach. Second Edition. Prentice Hall. Harlow.

Nirwana, Permasaran Jasa, Alta Pustaka, 2012

Rambat L.-A. Hamdani, Manajemen Pemasaran Jasa, Edisi 2, Salermba Empat, 2008, Jakarta.

Ratna Prima Lita, et al. (2010). Pengaruh Implementasi Bauran Pemasaran Jasa terhadap proses Keputusan Wisatawan Mengunjungi Obyek Wisata di Kota Padang, Journal Vol 2 No. 2, Des 2010, ISSN : 2085-09721

Schiffman, Leon., dan Kanuk, Leslie. 2010. Consumer Behavior. 10th edition. Prentice Hall Intl. New York. 
Sugiyono. 2012. Metode Penelitian Manajemen, 2014,. Alfabeta. Bandung.

Valdy R. Wowor,2013, Bauran Pemasaran Jasa, pengaruhnya terhadap kepuasan Konsumen pengguna Mobil Toyota Avanza Veloz PT. Hasjrat Abadi Manado, Jurnal EMBA 1229 Vol.1 No.4 Desember 2013, Hal. 1229-1239 ISSN 2303-1174 